Geohydrologic Significance of Lithofacies of the

Cockfield Formation of

Louisiana and Mississippi

and of the Yegua Formation of Texas

GEOLOGICAL SURVEY PROFESSIONAL PAPER 569-B 
Geohydrologic Significance of Lithofacies of the

Cockfield Formation of

Louisiana and Mississippi

and of the Yegua Formation of Texas

By J. N. PAYNE

GEOHYDR OLOGY OF THE CLAIBORNE GROUP

GEOLOGICAL SURVEY PROFESSIONAL PAPER 569-B

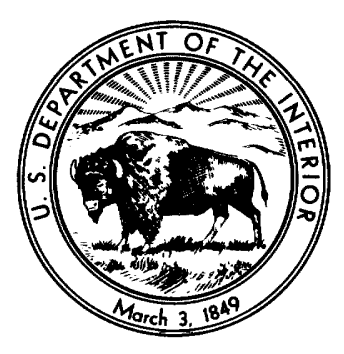




\section{UNITED STATES DEPARTMENT OF THE INTERIOR}

WALTER J. HICKEL, Secretary

GEOLOGICAL SURVEY

William T. Pecora, Director 


\section{CONTENTS}



Abstract

Page

B1 Hydrology

Permeability and transmissibility in relation to geologic factors.

Recharge and discharge

Regional flow

Chemical quality of water and relations to geologic and hydrologic factors.

Chemical provinces.

Dissolved so.ids...

Conclusions ........

3 Selected bibliography
Page

B4

4

5

5

6

6

7

11

11

\section{ILLUSTRATION S}

[Plates are in separate case]

Plate 1. Section $A-A^{\prime}-A^{\prime \prime}$ showing correlation of the Cockfield and Yegua Formations and associated formations in southwestern Louisiana and Texas.

2-7. Maps showing:

2. Structure contours on the top of the Cockfield and Yegua Formations in Louisiana, Mississippi, and Texas.

3. Sand-percentage distribution and thickness of the Cockfield and Yegua Formations in Louisiana, Mississippi, and Texas.

4. The maximum sand-unit thickness in the Cockfield and Yegua Formations in Louisiana, Mississippi, and Texas.

5. Estimated coefficients of transmissibility of the total sand thickness of the Cockfield Formation in Louisiana and Mississippi.

6. The piezometric surface and the altitude of the base of fresh ground water in the Cockfield Formation in Louisiana and Mississippi.

7. Dissolved-solids content, chemical provinces, and hardness distribution of waters in the Cockfield and Yegua Formations in Louisiana, Mississippi, and Texas.

8. Section $B-B^{\prime}$ showing correlation of Cockfield and associated formations and geologic-hydrologic relations in northeastern Louisiana and west central Mississippi.

Figure

1. Index map showing location of report area

2. Graph showing relation of specific conductance and water resistivity to dissolved-solids content of water from the sands of the Cockfield and Yegua Formations.

\section{TABLE}





\title{
GEOHYDROLOGIC SIGNIFICANCE OF LITHOFACIES OF THE COCKFIELD FORMATION OF LOUISIANA AND MISSISSIPPI AND OF THE YEGUA FORMATION OF TEXAS
}

\author{
By J. N. Payne
}

\begin{abstract}
The study of the Cockfield and Yegua Formations is the second part of an investigation of the geohydrology of the Claiborne Groupe of Eocene age.

The major structural features shown the structure-contour map of the top of the Cockfield and Yegua Formations are the north limb of the gulf coast geosyncline, the Mississippi embayment, La Salle arch, and Jackson dome. The Wiggins arch and Perry basin are refiected on the isopach map. Thickening and thinning of the Cockfield and Yegua Formations over structures indicate structural movement during Cockfield and Yegua time.

There are two depocenters in the Cockfield and Yegua Formations, one centered in the area of Montgomery, Liberty, and Hardin Counties, Tex., where the maximum thickness is about 1,700 feet, and the other is centered in the area of Duval and Webb Counties, Tex., where the maximum thickness exceeds $\mathbf{1 , 5 0 0}$ feet.

Sand-percentage and maximum sand-unit thickness maps show that the Cockfield and Yegua Formations in Louisiana, Mississippi, and eastern Texas consists of sediments deposited in a deltaic-fluvial-plain environment. An interlacing channel system was well developed in the area during Cockfield and Yegua time that is thought to be the record of the ancestral Mississippi and Trinity River systems. From Walker County, Tex., southwestward to Duval and Webb Counties, the maps of sand percentage and maximum sand-unit thickness suggest that an alongshore and nearshore environment of deposition was predominant.

The relation of permeability and transmissibility of the Cockfield Formation to geologic factors is similar to the relation found in the Sparta Sand. Limited data indicate that the coefficient of permeability increases with increase in thickness of the sand body. As a consequence of this relation between permeability and thickness, the areas of greater transmissibility are found along channel paths where thick sand units were deposited.

Recharge of the Cockfield and Yegua Formations is accomplished by direct precipitation in the outcrop area, by leakage from other aquifers, and, to a minor extent, by seepage from streams. Natural discharge from the Cockfield and Yegua Formations takes place primarily by leakage through overlying confining beds. The direction of flow of water in the Cockfield and Yegua Formations is toward the gulf coast geosyncline and the Mississippi River alluvial valley, as they are the two principal areas of discharge.
\end{abstract}

The water in the Cockfield and Yeguga Formations contains appreciable amounts of calcium and magnesium in, and for short distances downdip from, the outcrop and in the area where the Cockfield Formation is directly overlain by Mississippi River alluvium. In these areas the water is moderately to very hard. Based on anion ratios, waters from the cockfield and Yegua Formations have been grouped into (1) the bicarbonate-water province, (2) the chloride-water province, and (3) the sulfatewater province.

Differences in lithologic distribution and of altitude of the piezometric surfaces are vividly refiected in the regional distribution of the dissolved-solids content of waters in the sands of the Cockfield and Yegua Formations.

\section{INTRODUCTION PURPOSE AND SCOPE}

The investigation of the hydrologic significance of the lithofacies of the Cockfield and Yegua Formations was undertaken as the second part of a study of the geohydrology of formations of the Claiborne Group of Eocene age. The report on the results of this investigation describes and evaluates the relations of stratigraphy, stmucture, facies development, and depositional controls to the hydraulic characteristics of the Cockfield and Yegua Formations in parts of Louisiana, Mississippi, and Texas (fig. 1). No attempt was made to carry the investigation of the Cockfield Formation into Arkansas, which is adequately covered by a report on the Tertiary aquifers of the Mississippi embayment (Hosman and others, 1968, p. D22-D23). Future plans call for investigations and reports on the lower formations of the Claiborne Group and a summary report on all the aquifers of the Claiborne Group.

To accomplish the objectives of the investigation, data derived from electric logs of oil, gas, and other test wells, together with data from hydrologic tests, were used to prepare geologic and hydrologic maps and cross sections. The interpretation of the meaning and significance of the phenomena exhibited by the data on the maps and sections constitutes the body of the report. 


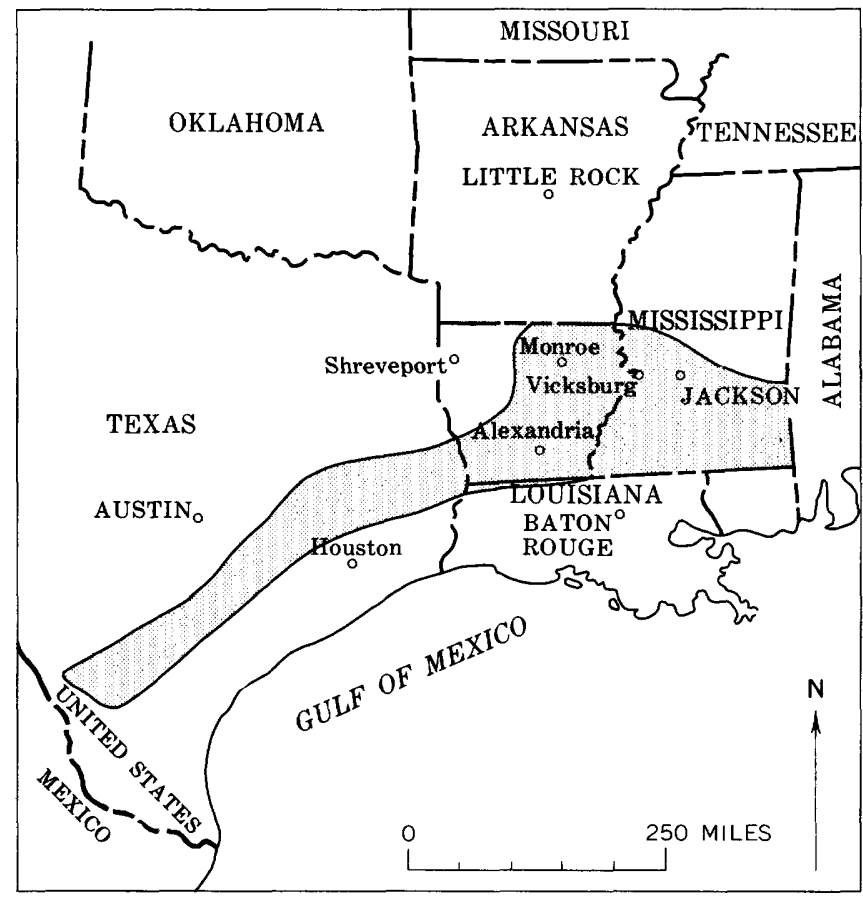

Figure 1.-Location of report area.

\section{ACKNOWLEDGMENTS}

Acknowledgment is made to the Louisiana Geological Survey, Department of Conservation; the Texas Water Development Board; and the Mississippi Oil and Gas Board for making available their log files. Acknowledgment is also made to the personnel of the district offices of the Water Resources Division of the U.S. Geological Survey in Louisiana, Mississippi, and Texas for supplying hydrologic and geologic information and for making many constructive suggestions and criticisms.

\section{GEOLOGY}

The Cockfield Formation (Vaughn, 1895, p. 220) of Louisiana and Mississippi and the equivalent Yegua Formation (Dumble, 1892, p. 124, 148-154) of Texas consist of sands, silts, and shales and minor amounts of lignite, bentonite, gypsum, and limestone. The sands are composed predominantly of fine- to medium-sized subangular to rounded quartz grains. The shales are generally silty and gray to dark chocolate brown. Gypsum is found in Texas, particularly in the southern part where it occurs as disseminated grains or as stringers in clays and shales of the Yegua Formation. Glauconitic sands are found in the upper part of the Cockfield Formation in Sabine Parish, La. (Treadwell, 1954, p. 2307). Some marine fossils, oyster beds, and limestone lenses have been found in the Yegua Formation in
Texas (Sellards and others, 1932, p. 674; Lonsdale, 1935 , p. 41; Lonsdale and Day, 1937, p. 56).

The correlation of the Cockfield and Yegua Formations as used in this report is shown in plates 1 and 8 . The correlations shown are based on electrical characteristics and may not correspond exactly to formational boundaries established from paleontological or paleobotanical evidence, but they do define what may be considered the Cockfield and Yegua aquifer system.

\section{STRUGTURE}

The structure-contour map (pl. 2, sheets 1 and 2) shows the altitude and configuration of the top of the Cockfield and Yegua Formations. Faulting has been shown only where it is necessitated by the magnitude and abruptness of changes in altitude of the top of the formation.

In northeastern Louisiana the regional dip of 15-50 feet per mile is to the east-southeast and southeast into the Mississippi embayment. In west-central Mississippi the regional dip is 15-50 feet per mile to the westsouthwest and southwest into the Mississippi embayment. The influence of the gulf coast geosyncline becomes dominant in central and southern Louisiana, where the regional dip is $50-100$ feet per mile to the south, and in southern Mississippi, where the regional dip is $25-100$ feet per mile to the south-southwest. In eastern Texas, from Sabine and Jasper Counties westward through Walker and Montgomery Counties, the regional dip is 100-250 feet per mile to the south-southeast into the gulf coast geosyncline. From Walker and Montgomery Counties, Tex., southwestward through Webb and Duval Counties, the regional dip is $150-250$ feet per mile southeastward into the gulf coast geosyncline.

Major structural features shown on the structurecontour map of the Cockfield and Yegua Formations are the north limb of the gulf coast geosyncline, Mississippi embayment, Jackson dome, and La Salle arch. The Wiggins arch and Perry basin of southern Mississippi (Murray, 1961, p. 107) are reflected on the isopach map of the Cockfield and Yegua Formations (pl. 3, sheet 1), but, because of post-Cockfield tilting, show little definition on the structure-contour map. All the major structures were developing during Cockfield and Yegua time, as reflected by the thickening or thinning of the Cockfield and Yegua Formations over the structures. (Compare pl. 2 , sheets 1 and 2 , and pl. 3, sheets 1 and 2.) Minor structures developing during Cockfield and Yegua time were the salt domes of eastern Louisiana and western Mississippi and the oil-field structures of southern Jasper, Newton, and Polk Counties, Tex. 


\section{THICKNESS}

There are two depocenters in the Cockfield and Yegua Formations. One lies in Montgomery, Liberty, and Hardin Counties, Tex., and the other in Duval and Webb Counties, Tex. In Montgomery and Hardin Counties the thickness of the formation is in excess of 1,700 feet (pl. 3, sheet 2 ). This depocenter is thought to represent the coalescing of a delta formed by an ancestral Trinity River (Sellards and others, 1932, p. 671) and a southwestward-extending lobe of a delta formed by the ancestral Mississippi River system. The depocenter extends east-northeast into Louisiana, and the thickness of the formations gradually diminishes to 750 feet on the west side of the Mississippi embayment. To the northwest of the depocenter, the thickness of the Cockfield and Yegua Formations decreases to about 900 feet near the outcrop in Texas and to about 500 feet near the outcrop in Louisiana. In western and southwestern Mississippi the Cockfield Formation is 400 feet thick. The minimum thickness of the Cockfield Formation is in the Wiggins arch area of southern Mississippi, where it is less than 50 feet. In the depocenter in Duval and Webb Counties, Tex., the thickness of the Yegua Formation is in excess of 1,500 feet and is thought to represent accumulation in the delta of an ancestral Rio Grande (Sellards and others, 1932, p. 671). Between the two depocenters in Texas the Yegua Formation has a fairly uniform thickness of about $900-1,000$ feet.

Local variations in thickness occur over Jackson dome, Perry basin, salt domes, and oil-field structures. (See pl. 2, sheets 1 and 2, and pl. 3, sheets 1 and 2.) Some local anomalous thimning of the Cockfield and Yegua Formations is probably a result of normal faulting.

\section{LITHOLOGIC VARIATIONS AND INTERPRETATIONS OF DEPOSITIONAL HISTORY}

The Cockfield and Yegua Formations are extremely variable in lithologic character, both laterally and vertically. An effective means of representing this variation in character is with a sand-percentage map on which the ratio of the total thickness of the sand in the formation to the total thickness of the formation is expressed as a percentage; that is :

Sand percentage $=\frac{\text { total thickness of sand }}{\text { total thickness of formation }} \times 100$.

The sand percentages for each logged section of the Cockfield and Yegua Formations were plotted on a map and grouped by 10-percent increments up to 80 percent. All values over 80 percent were included in one category (pl. 3, sheet 1). Another map, which complements the sand-percentage map, shows the thickest vertically continuous sand body in the Cockfield and Yegua Formations and is designated the maximum sand-unit thickness map (pl. 4, sheets 1 and 2).

Based on the pattern of sand concentration (pl. 3) and of maximum sand-unit thickness distribution ( $\mathrm{pl}$. 4), the Cockfield and Yegua Formations can be divided, for convenience of discussion, into two areas which seem to have differences in depositional environment. One area includes Louisiana, Mississippi, and that part of Texas extending westward from the Sabine River to Walker County; the other area is that part of Texas extending from Walker County south westward through Duval County and into Webb County.

The remarkable feature of the Louisiana-Mississippieastern Texas area is the well-developed lineal pattern of sand concentration and sand-unit thickness elements that trend north and northeast generally normal to the orientation of the presumed Cockfield and Yegua shoreline ( $\mathrm{pl} .3$, sheets 1 and 2 , and pl. 4 , sheets 1 and 2 ). The pattern of sand concentration and sand-unit thickness distribution is interpreted as the pattern of sediment distribution that resulted from deposition in the intricate system of channels and intervening swamps, marshes, and lakes developed in the delta and fluvial plain area of an ancestral Mississippi River.

Long meandering areas of high sand concentration ( $>40$ percent sand) are considered to be the sites of channel development that persisted throughout much of Cockfield and Yegua time. The general conformity in trend of the axes of thickening of maximum sand units and areas of high sand concentration is in harmony with the above interpretation. (Compare pl. 3, sheet 1 , and pl. 4, sheet 1.) Two good examples of high-sand-concentration lineaments occur in Mississippi. One lineament extends generally southward from Yazoo County through Hinds, Copiah, Lincoln, and Franklin Counties into Amite County. The other lineament extends from eastem Scott County southwestward through Smith, Covington, and Jefferson Davis Counties (pl. 3, sheet 1).

The percentage concentration of sand generally decreases from western and central Mississippi to the south and southwest. The axes of thickening of maximum sand units in the Louisiana-Mississippi-eastern Texas area probably represent the general location of channels at various times during the deposition of the Cockfield and Yegua Formations. The axes of thickening emphasize the interweaving of channels that would result from shifting channel positions in an area of lowgradient streams and heavy alluviation such as a delta and fluvial plain complex. Maximum sand-unit thicknesses greater than 100 feet are common in Mississippi and northeastern Louisiana but are rare in central and westem Louisiana and eastern Texas. 
In the Louisiana-Mississippi-eastern Texas area, the sand-percentage and sand-unit thickness maps indicate that a large delta was formed during Cockfield and Yegua time. The seaward edge of the Cockfield and Yegua delta extended from Wayne County, Miss., southwestward to southern Walthall County, Miss., thence west to west-southwest into eastern Texas (pl. 3, sheets 1 and 2). The sediments in this delta complex are predominantly continental, but many short-lived, localized invasions of the sea probably occurred which gave rise to the deposition of interfingering nearshore marine and brackish-water sédiments. Alongshore and offshore bars were deposited off the mouths of various distributaries of the delta system. The interpretation of the deltaic environment is in accord with findings of earlier investigators who worked in more local areas (Fisk, 1938, p. 88-89; 1940, p. 131-132; Grim, 1936, p. 137; Huner, 1939, p. 125; Thomas, 1942, p. 73 ).

In the area from Walker County, Tex., southwestward to Duval and Webb Counties, the orientation of the lineation of the sand-concentration pattern and of the maximum sand units is generally in a northeast direction parallel to the orientation of the postulated shoreline (pl. 3, sheet 2, and pl. 4, sheet 2). Maximum sand units more than 100 feet thick are relatively uncommon and of limited areal extent. The pattern of sand concentrations and of the maximum sand units is suggestive of deposition of sands as alongshore and nearshore bars interfingering with lagunal and nearshore clays and silts. The interpretation of the nearshore environment is supported by the reports of the occurrence of oyster reefs in the Yegua (Lonsdale, 1935, p. 41-43; Lonsdale and Day, 1937, p. 55; Sellards and others, 1932, p. 674$)$. In some areas, however, the long dimensions of the maximum sand units are oriented normal to the postulated shoreline, and the axes show a bifurcating pattern. These areas probably represent sands deposited in stream channels on small deltas formed at the mouths of predecessors of such streams as the Colorado and Guadalupe Rivers (pl. 4, sheet 2).

In southern McMullen County and in Duval County, the pattern of high sand concentration and of maximum sand-unit thickness together with the increased thickness of the Yegua Formation suggests a delta formed by an ancestral Rio Grande (pl. 3, sheet 2, and pl. 4, sheet 2).

The environmental conditions during the deposition of the Cockfield and Yegua Formations were in most respects a replica of the conditions of the present and of the recent past. The master system of sediment contribution was a Mississippi River system that probably differed from the present Mississippi River only in its exact location. Lesser contributions of sediment were made by streams that were the ancient counterparts of such present-day streams as the Rio Grande, Trinity, Colorado, and Guadalupe Rivers.

\section{HYDROLOGY}

In the Cockfield and Yegua Formations, we are dealing with an aquifier system made up of a number of imperfectly connected sand bodies, any one of which may act locally and for short periods of time as a distinct hydraulic unit.

\section{PERMEABLITY AND TRANSMISSIBILITY IN RELATION TO GEOLOGIC FACTORS}

In the Cockfield and Yegua Formations, individual sand units are extremely variable in thickness (pl. 4, sheets 1 and 2 , and pl. 8). The coefficient of permeability ${ }^{1}$ also has a wide range in value-from $15 \mathrm{gpd}$ per sq $\mathrm{ft}$ (gallons per day per square foot) for sands 15-20 feet thick to about $400 \mathrm{gpd}$ per sq ft for sands 100 feet or more thick. Data on the coefficient of permeability of the sands of the Cockfield and Yegua Formations are less abundant than those for the Sparta Sand. Available permeability data suggest a relation between permeability and sand thickness similar to that noted for the Sparta Sand; that is, the coefficient of permeability increases as the sand thickness increases (Payne, 1968, p. A5). The following tabulation shows the average coefficient of permeability for sand units ranging from 15 to 150 feet in thickness.

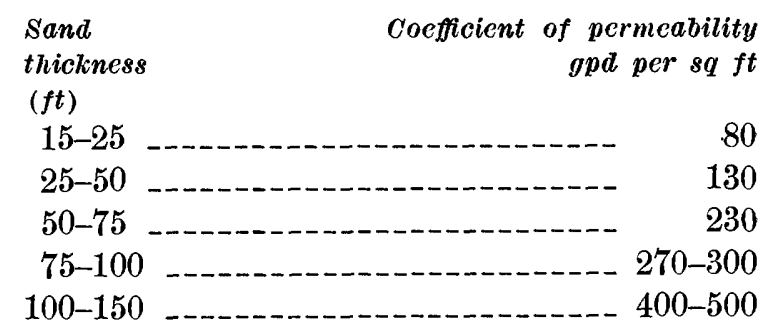

The permeability values were used to calculate the transmissibility ${ }^{2}$ of the cumulative thickness of sands

\footnotetext{
1 The coefficient of permeability is defined as the rate of flow of water, in gallons per day, through a cross-sectional area of the aquifer 1 foot square under a hydraulic gradient of 100 percent, or 1 foot per foot at a temperature of $60^{\circ} \mathrm{F}\left(16^{\circ} \mathrm{C}\right)$. The "field" coefficient of permeability is the same rate of fow under the prevailing conditions of water temperature (Meinzer and Wenzel, 1942, p. 452).

2 The coefficient of transmissibility is the field coefficient of permeability multiplied by the thickness, in feet, of the aquifer (Theis, 1935 , p. 520). Bredehoeft $(1964$, p. D168) elaborated on this definition to account for an aquifer made up of layers of differing permeabilities as :

$$
T=\Sigma K_{t} m,
$$

where $i=1,2,3, \ldots n$ layers of differing permeablity, $T=$ transmissibility,

$K_{i}=$ permeability of the $i$ layer,

and $m_{i}=$ thickness of the $i$ layer.
} 
in the Cockfield Formation of Louisiana and Mississippi (pl. 5). No calculations of the transmissibility of the Yegua Formation of Texas were made because sufficient data on permeability are available only in a rather limited area in eastern Texas. Information on transmissibility of the Yegua Formation in a substantial part of eastern Texas has been published recently (Anders, 1967, p. 25).

Transmissibility of the cumulative sand thickness of the Cockfield Formation, although extremely variable locally, is generally higher in western and west-central Mississippi than it is to the southeast in Mississippi and to the west and southwest in Louisiana (pl. 5). In western and west-central Mississippi, the maximum coefficient of transmissibility calculated was $170,000 \mathrm{gpd}$ per ft (gallons per day per foot), whereas in Louisiana the maximum coefficient of transmissibility calculated was 85,000 gpd per $\mathrm{ft}$. The generally higher transmissibility in western and west-central Mississippi is a reflection of the higher sand concentration and development of thicker and more extensive maximum sand units in western and west-central Mississippi than elsewhere in the area. (Compare pl. 3, sheet $1 ;$ pl. 4, sheet 1 ; and pl.5.)

\section{RECHARGE AND DISCHARGE}

Recharge of the Cockfield Formation of Louisiana and Mississippi is accomplished directly by precipitation in the outcrop area, by movement of water from other aquifers, and by a very minor amount of infiltration from streams. The Yegua Formation of Texas is recharged by precipitation in the outcrop area and by infiltration of water from streams and movement of water from other aquifers.

Discharge from the Cockfield and Yegua Formations occurs by withdrawal from wells and by natural discharge. The largest withdrawals by wells have occurred in the Jackson, Miss., area, where the Cockfield Formation serves as the source of supply for industries and for smaller municipalities in the environs of Jackson. Natural discharge takes place primarily by leakage of water from the Cockfield and Yegua Formations through the overlying confining beds and, to a lesser extent, by movement of water into streams incised into the formations.

\section{REGIONAL FLOW}

Artesian conditions exist in the greater part of the area. The flow of water in an artesian aquifer is brought about by differences in head modified by friction and molecular attraction. The amount of water that has been withdrawn by pumping from the Cockfield and Yegua Formations is a negligible part of the water that is contained in the formation; therefore, from the re- gional standpoint the Cockfield and Yegua Formations form a balanced hydrologic system in which the amount of recharge is equal to the amount of discharge. In Texas, western Louisiana, and southeastern Mississippi, the direction of flow is down the regional dip toward the gulf coast geosyncline. In eastern and central Louisiana and western and central Mississippi, the direction of flow is toward the Mississippi River alluvial valley. The general directions of flow are reflected by the direction of increasing depth and limit of fresh water and the slope of the piezometric surface (pl. 6) and by the directions of increasing dissolved-solids content ( $\mathrm{pl} .7$, sheets 1 and 2 , and pl. 8 ).

The relations of recharge, discharge, and regional flow in the Cockfield and Yegua Formations to the geologic framework and differences in piezometric surfaces are similar to the relations of these factors in the Sparta Sand. As the relations are discussed in some detail in the chapter on the Sparta Sand (Payne, 1968, p. A6-A8), they will only be briefly summarized at this point. Water from precipitation in the upland areas enters the Cockfield and Yegua Formations either directly or by downward percolation through surficial material. Within short distances downdip the water is in an artesian system confined by the clays of the Cook Mountain Formation and Jackson Group. In the area where the piezometric surface of the Cockfield and Yegua is higher than that of the Sparta Sand and lower than the overlying aquifers, the flow is generally downward nearly parallel to the dip of the formation. Where the piezometric surface of the Cockfield and Yegua becomes higher than the piezometric surface of the overlying aquifers, generally in the deeper fresh-water areas near the limit of fresh water, the dominant movement is upward (pl. 8). The effect of these relations on the dissolved-solids content of the waters in the Cockfield and Yegua formations is discussed in the section on "Dissolved Solids" (p. B10-B11).

The relation of rate of flow and degree of flushing by fresh water to the thickness, relative continuity, and orientation of the sand bodies in the Cockfield and Yegua Formations is similar to that for the Sparta Sand (Payne, 1968, p. A8). In areas of low sand concentration (pl. 3, sheets 1 and 2), the sand bodies are usually relatively thin and form a disconnected or imperfectly connected system where flow is retarded by intervening shales, clays, and silts. In areas of high sand concentration and particularly along channel paths such as in western and south-central Mississippi (axes of thickening, pl. 4, sheet 1) where massive overlapping sand bodies occur, the reduction in permeability is only slight to moderate, and freedom of water movement is not drastically affected. The channel paths, particularly 
where oriented generally parallel to the direction of flow, are favorable areas for water movement and, consequently, are an important factor in the degree of flushing by fresh water. (Compare pls. 5, 6, and 7.) In Texas the maximum sand units of the Yegua Formation are thinner, of limited extent, and oriented generally normal to the direction of flow. The freedom of water movement is greatly impeded, and there is considerably less flushing by fresh water than in western and central Mississippi (pl. 7, sheets 1 and 2). In Louisiana, poorer and less extensive development of favorably oriented sands in the Cockfield Formation also contributes to less extensive flushing by fresh water downdip from the outcrop area.

\section{CHEMICAL QUALITY OF WATER AND RELA- TIONS TO GEOLOGIC AND HYDROLOGIC FACTORS}

Data from chemical analyses in the files of the Water Resources Division of the U.S. Geological Survey and in published reports, together with calculations from electric logs of dissolved-solids content, have been used to prepare a map showing some of the important chemical characteristics of waters in the Cockfield and Yegua Formations (pl. 7). ${ }^{3}$ The relation of the regional variations of quality of water in the Cockfield and Yegua Formations to geologic and hydrologic factors has been analyzed by comparing the map showing the chemical characteristics to maps showing geologic and hydrologic data (pls. 3, 4, 5, and 6).

The chemical analyses represent waters in the zones sampled and are not representative of the water quality in other zones and in other areas of the Cockfield and Yegua Formations. Therefore, in the boundary areas of any water province, which may be outlined from the analyses of individual zones, it is reasonable to assume that other sands in the Cockfield and Yegua Formations in the same area may have water of a different chemical type.

\section{CHEMICAL PROVINCES}

Only the constituents that make up the bulk of dissolved-solids content as shown by analyses of water from the Cockfield and Yegua Formations are considered in this report. Regionally, sodium is the dominant cation (table 1). Calcium and magnesium occur in significant amounts in and for relatively short distances downdip from the outcrop area and in the area where the Cockfield Formation is directly overlain or in proximity to the Mississippi River alluvium. As hardness is a reflection of the calcium magnesium content, a

\footnotetext{
${ }^{3}$ Since October 1, 1967, the U.S. Geological Survey has reported results of chemical analyses in milligrams per liter $(\mathrm{mg} / \mathrm{l})$ instead of in parts per million (ppm). In the fresh through moderately saline water range, $\mathrm{mg} / \mathrm{l}$ are virtually equal to $\mathrm{ppm}$.
}

line showing the areas in which the hardness is greater than 60 milligrams per liter $(\mathrm{mg} / \mathrm{l})$ (the division between "hard" and "soft" water) is a convenient means of indicating areas in which the calcium magnesium content is apt to be in excess of $20 \mathrm{mg} / \mathrm{l}$ (pl. 7). An examination of the distribution of the hardness indicates a rapid reduction in calcium and magnesium content in the direction of flow and is probably a reflection of the base exchange capacities of the clays in and directly overlying and underlying the Cockfield and Yegua Formations. Limited data indicate, however, that as the degree of flushing decreases, the calcium magnesium content increases. (See wells TLO-1, TMM-1, and LRa-1, table 1.)

The dominant anions of the waters from the Cockfield and Yegua Formations are bicarbonate $\left(\mathrm{HCO}_{3}\right)$, chloride $(\mathrm{Cl})$, and sulfate $\left(\mathrm{SO}_{4}\right)$. As suggested by Hem $(1959$, p. 155-156), the ratios of these anions in milliequivalents per liter (me/l) were calculated and the resulting values plotted on a map. Examination of the data showed that, based on these rational values, the waters of the Cockfield and Yegua Formations can logically be divided into three chemical provinces: the bicarbonate-water province; the chloride-water province; and the sulfate-water province (pl. 7).

Bicarbonate-water province.-This province is defined by the condition that the ratio of the bicarbonate anions to the sum of the chloride and sulfate anions is $\supseteq 1$. The province covers a narrow strip in and a short distance downdip from the outcrop in west-central Louisiana. From Winn Parish northeastward the bicarbonate-water province widens abruptly and covers an appreciable area in central and northeastern Louisiana. It also includes the greater part of Mississippi, but in Texas it is limited to a narrow band extending from the Louisiana-Texas line west-southwestward to Brazos County and to a small area in Gonzales County. (See pl. 7, sheet 2.) The distribution of the bicarbonate-type water in the Cockfield Formation is related to the extent, in both time and space, of flushing by fresh water. This is indicated by comparing the position of the limit of the bicarbonate province, the line where bicarbonate : chloride + sulfate $=1$, to the limits of fresh water (pl. 6 and the $1,000 \mathrm{mg} / 1$ minimum dissolvedsolids line, pl. 7). In Louisiana the limit of the bicarbonate-water province coincides roughly with the limit of fresh water (less than $1,000 \mathrm{mg} / 1$ dissolved solids), whereas in Mississippi the bicarbonate-water province extend's to the $3,000 \mathrm{mg} / 1$ dissolved-solids content line. This difference is a result of the fact that the piezometric surface of the Cockfield Formation in Mississippi is considerably higher than in Louisiana and that there has been a deeper and more thorough flushing by fresh 
water of the Cockfield Formation on the Mississippi side of the saline-water area under the alluvial valley. (See pls. 6 and 7, fig. 2, and the discussion of "Dissolved Solids," p. B10-B11.)

Chloride-water province.-This province is defined by the condition that the ratio of the chloride anions to the sum of the bicarbonate and sulfate anions is $\supseteq$ 1. In Louisiana it corresponds, in general, to the area where the minimum dissolved-solids content of the waters in the sand of the Cockfield Formation is greater than $1,000 \mathrm{mg} / \mathrm{l}$ (pl. 7). In a few small areas in Louisiana, such as in La Salle and Morehouse Parishes, fresh waters (less than $1,000 \mathrm{mg} / \mathrm{l}$ dissolved solids) are of the chloride type. In Mississippi the chloride-water province is largely confined to that area in which the minimum dissolved-solids content is greater than 3,000 $\mathrm{mg} / \mathrm{l}$ (pl. 7). In Texas the chloride-water province includes all the area underlain by the Yegua Formation except for a narrow band lying along and a short distance downdip from the outcrop. The chloride-type waters represent, in general, the areas of discharge along the flanks of the gulf coast geosyncline and under the Mississippi River alluvial valley where there has been little or no flushing by fresh water (pls. 6, 7, and 8).

Sulfate-water province.-The analyses of waters from the sands of the Cockfield and Yegua Formations were studied in relation to information on the mineralogical content of the Cockfield and Yegua and the subjacent and superjacent formations. The results of this examination suggested that the presence of sulfate in proportions greater than 30 percent of the total anions shown in the analyses of the waters from the Cockfield and Yegua was indicative of the presence of gypsiferous beds in the Cockfield and Yegua and associated formations. As this is of geological significance, the condition where the ratio at the sulfate anions to the sum of the bicarbonate and chloride anions is $\supseteq$ 0.5 was chosen to define the sulfate-water province. This ratio limit means that the sulfate-water province may include waters that are mixed bicarbonate-, chloride-, and sulfate-type waters (table 1, well TGz-1) as well as true sulfate-type waters (table 1, well TK-1.) Almost all the sulfate-water province lies in Texas, where it extends as a virtually continuous belt, lying in and a short distance downdip from the outcrop, from Brazos County southwestward to the border between the United States and Mexico at Laredo, Tex. (pl. 7). Northeastward from Brazos County to the LouisianaTexas line, there are a few small isolated areas of sulfate-type waters. In Louisiana there are two small areas of sulfate water, one in Sabine Parish and the other in Caldwell Parish. In Mississippi a small area of sulfate water is found in Rankin County.

\section{DISSOLVED SOLIDS}

The mapping of the dissolved-solids content of water on a regional scale is an excellent means of gaining a better understanding of the relation of water movement and variations in chemical quality of waters to geologic and hydrologic factors. The relation of dissolved-solids content to the specific conductance of water is constant up to concentrations of at least 10,000 $\mathrm{mg} / \mathrm{l}$ dissolved solids (fig. 2). A satisfactory method for calculating the dissolved-solids content of water in an aquifer from the long-normal resistivity curve of electric logs was described by Turcan $(1966$, p. $3-13) .{ }^{4}$ This method was used to calculate the dissolved-solids content of water in the sands of the Cockfield and Yegua Formations. The values obtained from the calculations, together with data from chemical analyses, were used to prepare a map showing the regional variations of the dissolved-solids content of water in the sands of the Cockfield and Yegua Formations (pl. 7). ${ }^{5}$ To avoid mechanical errors, no calculations were made for sands less than 20 feet thick.

For Louisiana and Mississippi, three sets of values were calculated to show the range of variation of the dissolved-solids content of water in the sands of the Cockfield Formation. These are (1) the minimum dissolved-solids content, which represents the water having the lowest dissolved-solids content in the entire Cockfield section; (2) the maximum dissolved-solids content, which represents the water having the highest dissolvedsolids content in the entire Cockfield section; and (3) the weighted average dissolved-solids content, which is derived by assuming an equal porosity for all the sands and weighting the dissolved-solids content proportionately for the thickness of each sand in the section for which calculations were made (Payne, 1968, p. A14). For Texas, only the minimum and maximum dissolvedsolids contents are shown.

The distribution of the dissolved-solids content of the waters in the Cockfield and Yegua Formations is a reflection of the effects of geologic and hydrologic factors on water movement and on the extent of flushing by fresh water. The influence of the development and orientation of the massive sand units (channel paths)

\footnotetext{
4 Turcan's method is based on the equation:

$$
F, \frac{R_{0}}{R_{w}}
$$

where

$F_{f}=$ the field formation resistivity factor,

$R_{0}=$ the resistivity read from the long-normal curve corrected to $77^{\circ} \mathrm{F}\left(25^{\circ} \mathrm{C}\right)$,

$R_{w}=$ the resistivity of the water at $77^{\circ} \mathrm{F}\left(25^{\circ} \mathrm{C}\right)$.

5 On the map showing the dissolved-solids content of waters in the sands of the Cockfield and Yegúa Formations (pl. 7), the contour intervals of $500,1,000,3,000,10,000$ and $35,000 \mathrm{mg} / \mathrm{l}$ dissolved solids were chosen on the basis of the standards proposed by the U.S. Health Service (1962) and the salinity classification given by Winslow and Kister (1956, p. 5).
} 


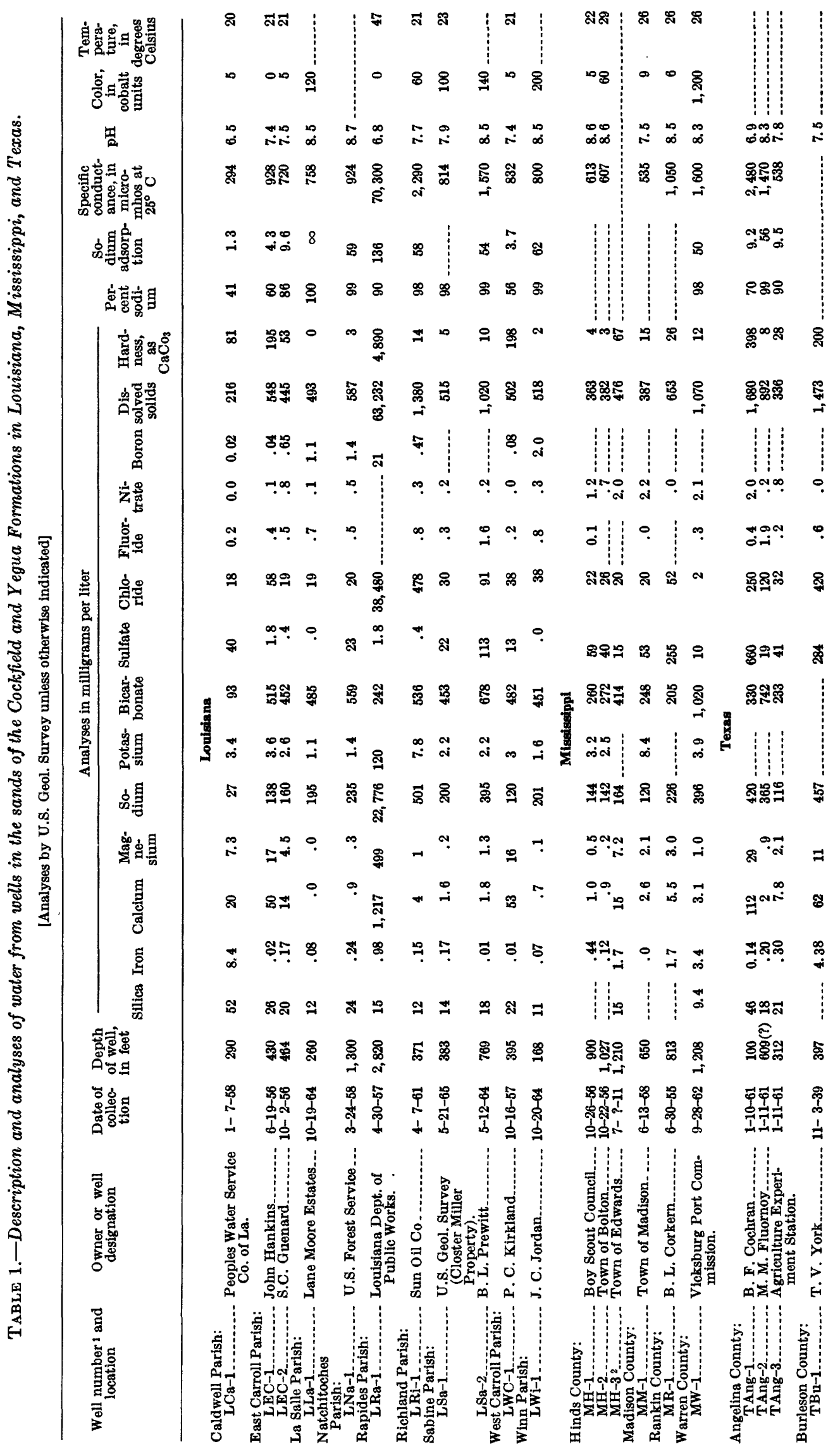




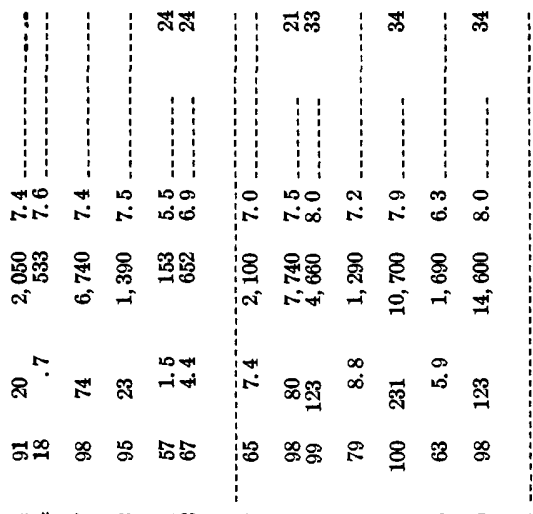

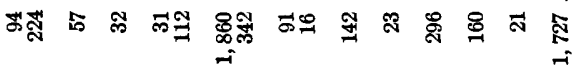



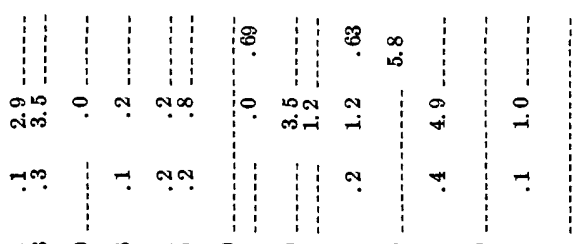

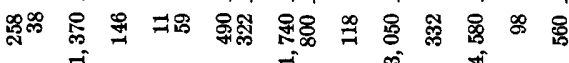

ॠำ

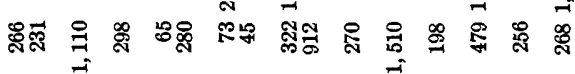

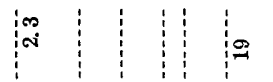

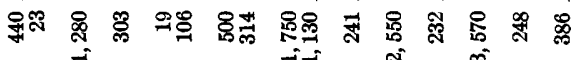

ind

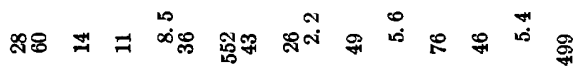



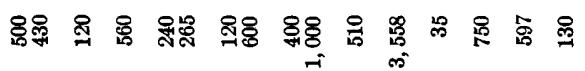

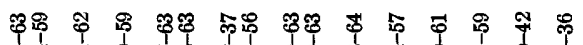

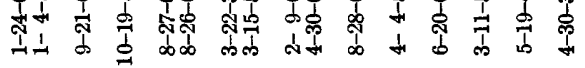

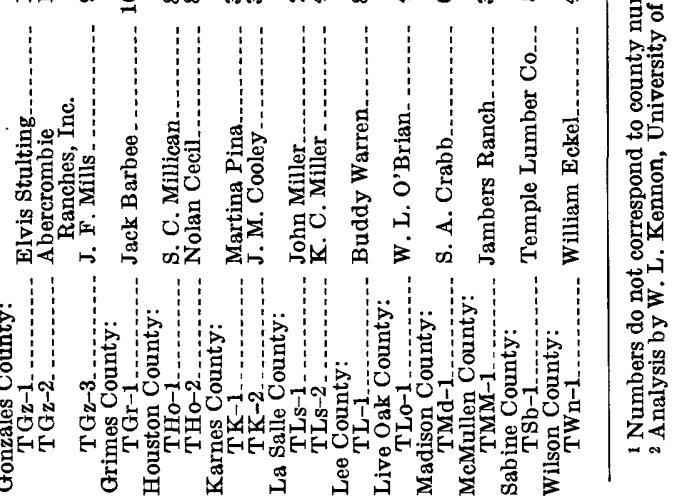






FIgURE 2.-Relation of specific conductance and water resistivity to dissolved-solids content of water from the sands of the Cockfield and Yegua Formations.

on the flow of the fresh water and the extent of flushing by fresh water is well reflected. In Mississippi where massive sand units are well developed and generally oriented with the long dimension parallel to the direction of flow, the contours representing the dissolvedsolids content show pronounced deflection in a downdip or downflow direction along the axes of thickening of the maximum sand units. (Compare pls. 5, 6, and 7.) The correlation of dissolved-solids and maximum sand units is less perfect in Louisiana where the maximum sand units are less well developed and less favorably oriented with respect to direction of flow. In Texas where the massive sand units in the Yegua Formation are generally not well developed and where the long dimension of the maximum sand units is oriented generally normal to the direction of flow, there has been no extensive flushing by fresh water. This lack of flush- ing by fresh water is indicated by the high dissolvedsolids content of waters in the sands of the Yegua Formation in and short distances downdip from the outcrop (pl. 7).

The difference in altitude of the piezometric surface of the Cockfield Formation in Louisiana and the piezometric surface of the Cockfield Formation in Mississippi is strikingly reflected in the map showing the dissolvedsolids content of waters in the Cockfield (pl. 7). In Mississippi the piezometric surface of the Cockfield is considerably higher than it is in Louisiana (pls. 6 and 8 ). This relation of the piezometric surfaces accounts, in part, for the greater penetration of lower dissolvedsolids content waters downdip from the outcrop in Mississippi than in Louisiana (pls. 6, 7 and 8). The "stacking" of the isodissolved-solids contours on the west or Louisiana side of the saline-water area as com- 
pared to the "spreading" of the contours on the east or Mississippi side is also a reflection, in part, of the differences in altitude of the piezometric surfaces.

Plate 8 is a section extending from northern La Salle Parish, La. to north western Hinds County, Miss., showing the calculated dissolved-solids content of waters in the sands of the Cockfield Formation, Sparta Sand, Meridian Sand, Wilcox Formation, and Wilcox Group. The dissolved-solids content of the various sands has been plotted graphically, using the zero-resistivity line of the electric $\log$ as the zero base for the dissolvedsolids content. As can be seen, the piezometric surface of the water in the Cockfield Formation on the east side of the Mississippi River alluvial valley is 50-100 feet higher than the corresponding piezometric surface on the west side of the valley. In response to the difference in head reflected in this difference in water levels, the base of the fresh water in the Cockfield Formation is $400-500$ feet lower on the east side of the alluvial valley than on the west side. (See also pl. 6.) Furthermore, the lateral increase in dissolved-solids content of the waters in the sands of the Cockfield Formation is much more gradual on the east side of the alluvial valley than on the west side, a condition that is also a response, in part, to the differences in altitude of the opposing piezometric surfaces of the waters of the Cockfield. In effect, the saline-water core is under the western part of the Mississippi River alluvial valley and situated well up on the west flank of the Mississippi embayment (pl. 8 , and compare pls. 2 and 7 ). Physical conditions and effects similar to those discussed for the Cockfield can be seen to occur in the Sparta and Meridian Sands (pl. 8).

The relation of the piezometric surface of the Cockfield Formation to the piezometric surface of the Sparta Sand is reflected in the dissolved-solids content of waters in the two formations.

Along the marginal areas of the Mississippi River alluvial valley, the piezometric surface of water in the Sparta Sand is higher than the piezometric surface of water in the Cockfield Formation (pl. 8). This relation of piezometric surfaces in the two formations causes water in the Sparta Sand to move upward into the Cockfield Formation. On the east side of the Mississippi alluvial valley, fresh water in the Sparta has moved farther downdip than has the fresh water in the Cockfield, and fresh water in the Sparta has underrun saline waters in the Cockfield. (See pl. 6, note relative positions of limits of fresh water, and pl. 8.) The upward movement of fresher waters from the Sparta Sand into the Cockfield Formation has probably aided in the reduction of the dissolved-solids content of the waters of the Cockfield Formation on the east side of the Missis- sippi River alluvial valley and thus contributed to the previously mentioned downdip displacement and "spreading" of the contours showing dissolved-solids content (pls. 7 and 8).

\section{CONCLUSIONS}

1. In the Cockfield and Yegua Formations the most important geological factor affecting the hydrology is the mode of deposition. The area in which the Cockfield and Yegua Formations are of prime importance as a source of fresh water is the area in which well-developed channel sands, characteristic of deltaic and fluvial plain areas, were deposited.

2. In the channel sands the coefficient of permeability increases with an increase in thickness of the sand unit.

3. A higher degree of flushing takes place along the axes of thickening of well-developed and favorably oriented maximum sand units (channel paths) than in intervening areas.

4. Well-developed maximum sand-unit areas offer optimum locales for exploration for large supplies of fresh and saline ground water.

5. The regional flow pattern of the fresh ground water, in which the Cockfield is of prime importance as a fresh-water aquifer, is controlled by the Mississippi River alluvial valley.

6. Leakage of fresh water from the Sparta Sand into the Cockfield Formation has contributed substantially to the downdip extension of fresh water in the Cockfield on the east side of the Mississippi River alluvial valley.

7. High sulfate content in waters from the Cockfield and Yegua Formations are generally related to the gypsum content of the Cockfield and Yegua and associated formations.

8. Mapping and plotting of the dissolved-solids content of the waters of the Cockfield and Yegua Formations are effective means for better understanding the relations of the geology and hydrology of the formation.

9. The geologic, hydrologic, and chemical maps of the Cockfield and Yegua Formations constitute a base for the quantitative evaluation and description of the Cockfield and Yegua aquifer system.

\section{SELECTED BIBLIOGRAPHY}

[Annotated for publications containing specific information on the Cockfield and Yegua Formations]

Alexander, W. H., Jr., Myers, B. N., and Dale, O. C., 1964, Reconnaissance investigation of the ground-water resources of the Guadalupe, San Antonio, and Nueces River basins, Texas: Texas Water Comm. Bull. 6409, 106 p.

Brief description of lithology and fresh-water potential of Yegua Formation. 
Alexander, W. H., Jr., and White, D. E., 1966, Ground-water resources of Atascosa and Frio Counties, Texas: Texas Water Devel. Board Rept. 32, 200 p.

Brief description of outcrop, lithology, and thickness. Brief discussion of chemical quality and available quantity of water in Yegua Formation. Records of wells and chemical analyses given in tables.

Anders, R. B., 1957, Ground-water geology of Wilson County, Texas: Texas Board Water Engineers Bull. 5710, 62 p.

Brief discussion of geology and water characteristics and potential of Yegua Formation. Geologic maps and cross sections given on plates. Records of wells and chemical analyses given in tables.

1960, Ground-water geology of Karnes County, Texas: Texas Board Water Engineers Bull. 6007, 107 p.

Discussion of geology and ground-water potential of Yegua Formation. Geologic map and cross sections on plates. Records of wells, chemical analyses, and comparative levels of selected wells for periods 1936-37 and 1955-56 in tables.

1967, Ground-water resources of Sabine and San Augustine Counties, Texas: Texas Water Devel. Board Rept. 37, $115 \mathrm{p}$.

Brief discussion of geology of Yegua Formation. Discussion of aquifer potential, permeability and transmissibility, and fresh-water availability. Geologic map and cross sections on plates. Records of wells and chemical analyses in tables.

Anders, R. B., and Baker, E. T., Jr., 1961, Ground-water geology of Live Oak County, Texas: Texas Board Water Engineers Bull. 6105, $119 \mathrm{p}$.

Brief description of geology of Yegua Formation and of quality of water in the formation. Geologic sections on plates. Chemical analysis and record of well in table.

Andersen, H. V., 1960, Geology of Sabine Parish: Louisiana Geol. Survey. Geol. Bull. 34, 164 p.

Discussion of geology and stratigraphic relations of the Cockfield Formation.

Baker, B. B., Dillard, J. W., Souders V. L., and Peckham, R. C., 1963, Reconnaissance investigation of the ground-water resources of the Sabine River basin, Texas: Texas Water Comm. Bull. 6307, 57 p.

Very brief description of geology and hydrology of the Yegua Formation. Geologic map and cross section on plates.

Baker, B. B., Peckham, R. C., Dillard, J. W., and Souders, V. L., 1963, Reconnaissance investigation of the ground-water resources of the Neches River basin, Texas: Texas Water Comm. Bull. 6308, 67 p.

Fairly detailed description of hydraulic properties of Yegua Formation. Discussion of water quality and use. Brief description of geology. Geologic map and cross sections on plates.

Bergquist, H. R., and McCutcheon, T. E., 1942, Scott County geology : Mississippi Geol. Survey Bull. 49, $146 \mathrm{p}$.

Description of geology and stratigraphic relations of the Cockfield Formation. Geologic map.

Bornhauser, Max, 1947, Marine sedimentary cycles of Tertiary in Mississippi embayment and central Gulf Coast area :
Am. Assoc. Petroleum Geologists Bull., v. 31, no. 4, p. 698-712.

Discusses history of deposition and structural evolution of the Cook Mountain-Cockfield cycle.

Bredehoeft, J. D., 1964, Variations of permeability in the Tensleep Sandstone in the Bighorn Basin, Wyoming as interpreted from core analyses and geophysical logs, in Geological Survey research 1964: U.S. Geol. Survey Prof. Paper 501-D, p. D166-D170.

Brown, G. F., 1947, Geology and artesian water of the alluvial plain in northwestern Mississippi: Mississippi Geol. Survey Bull. 65, $424 \mathrm{p}$.

Discusses the geology and hydrology of the Cockfield Formation. Chemical analyses, records of wells, and waterlevel declines prior to 1939 in tables.

Callahan, J. A., 1963, Ground-water resources in Yazoo County, Mississippi : Mississippi Board Water Commissioners Bull, 63-5, $42 \mathrm{p}$.

Discussion of structure, hydrology, and chemical quality of water. Stratigraphic summary, water-bearing properties, records of wells, and chemical analyses in tables. Geologic cross section.

Chawner, W. D., 1936, Geology of Catahoula and Concordia Parishes: Louisiana Dept. Conserv. Geol. Bull. 9, 232 p.

History of use of name Cockfield and definition of the formation. Detailed description of geology of the formation. Structure of top of Cockfield and geologic map on plates.

Cronin, J. G., Follett, C. R., Shafer, G. H., and Rettman, P. L., 1963, Reconnaissance investigation of the ground-water resources of the Brazos River basin, Texas: Texas Water Comm. Bull. 6310, 152 p.

Brief description of geology and hydrology of the Yegua Formation. Chemical analyses in table. Geologic map and cross section on plate and figure.

Cushing, E. M., Boswell, E. H., and Hosman, R. L., 1964, General geology of the Mississippi embayment: U.S. Geol. Survey Prof. Paper 448-B, 28 p.

Very brief discussion of Cockfield Formation.

Deussen, Alexander, 1914, Geology and underground waters of the southeastern part of the Texas Coastal Plain: U.S. Geol. Survey Water-Supply Paper 335, 365 p.

Describes the geology of the Yegua Formation. Discusses water potential by counties. Few chemical analyses in text.

DeVries, D. A., Moore, W. H., Kern, M. K., Morse, H. M., and Murray, G. E., 1963, Jasper County mineral resources: Mississippi Geol. Econ. and Topog. Survey Bull. 95, 101 p.

Description of geology and stratigraphic relations of Cockfield Formation. Discussion of water resources of Cockfield aquifer. Records of wells and chemical analyses in tables. Geologic map and isopach map of Cockfield aquifer on plates.

Dixon, L. H., 1965, Cenozoic cyclic deposition in the snbsurface of central Louisiana: Louisiana Geol. Survey Geol. Bull. $42,124 \mathrm{p}$.

Dumble, E. T., 1892, Report on the brown coal and lignite of east Texas: Texas Geol. Survey, 243 p. 
Ellisor, A. C., 1929, Correlation of the Claiborne of east Texas with the Claiborne of Louisiana: Am. Assoc. Petroleum Geologists Bull., v. 13, no. 10, p. 1335-1346.

Brief description of Cockfield Formation. Correlation shown on plate.

Fisk, H. N., 1938, Geology of Grant and La Salle Parishes: Louisiana Dept. Conserv. Geol. Bull. 10, 246 p.

Detailed description of geology of Cockfield Formation. Discusses conditions of deposition.

1940, Geology of Avoyelles and Rapides Parishes : Louisiana Dept. Conserv. Geol. Bull. 18, 240 p.

Description of lithology of Cockfield in subsurface.

1944, Geological investigation of the alluvial valley of the low Mississippi River: U.S. Dept. Army, Corps of Engineers, Mississippi River Comm., 78 p. [1945].

Grim, R. E., 1936, The Eocene sediments of Mississippi : Mississippi Geol. Survey Bull. 30, 240 p.

Lithologic and mineralogic description of samples from various sections of Cockfield Formation. Discusses interpretation of depositional environments.

Harris, H. B., 1965, Ground-water resources of La Salle and McMullen Counties, Texas : Texas Water Comm. Bull. 6520, $96 \mathrm{p}$.

Very brief description of Yegua Formation. Brief discussion of water availability. Records of wells and chemical analyses in tables. Geologic map and cross sections on plates.

Harvey, E. J., Callahan, J. A., and Wasson, B. E., 1961, Groundwater resources of Hinds, Madison, and Rankin Counties, Mississippi, Part II, Basic data: Mississippi Board Water Commissioners Bull. 61-2, 146 p.

Brief description of lithology and water-bearing properties of Cockfield Formation. Records of wells, data on municipal supplies, description of drill cuttings, and chemical analyses in tables.

1964, Ground-water resources of Hinds, Madison, and Rankin Counties, Mississippi: Mississippi Board Water Commissioners Bull. 64-1, 38 p.

Description of geology of Cockfield Formation. Discussion of hydrology and water development. Figures show geologic cross sections, structure, and thickness of the Cockfield. Records of wells, data on pumpage for municipal supplies, chemical analyses, and results of pumping tests in tables.

Harvey, E. J., and Grantham, P. E., 1963, Interim report on the hydrology of the Cockfield Formation in the vicinity of Jackson, Mississippi: Mississippi Board Water Commissioners Bull. 63-6, $18 \mathrm{p}$.

Fairly detailed discussion of the geology of Cockfield Formation. Detailed discussion of water movements, recharge, discharge, and water supply in the Cockfield. Decribes results of pumping tests and variations in transmissibility. Figures show structure of the top of the Cockfield, thickness of the Cockfield, and the piezometric surface.
Hem, J. D., 1959, Study and interpretation of the chemical characteristics of natural water: U.S. Geol. Survey WaterSupply Paper 1473, $269 \mathrm{p}$.

Hosman, R. L., Long, A. T., Lambert, T. W., and others, 1968, Tertiary aquifers in the Mississippi embayment, with discussion on Quality of the Water, by H. G.' Jeffrey : U.S. Geological Survey Professional Paper 448-D, 29 p.

Huner, J. H., Jr., 1939, Geology of Caldwell and Winn Parishes : Louisiana Dept. Conserv. Geol. Bull. 15, 356 p.

Discusses history of investigations, establishment, and definition of name "Cockfield." Detailed description of geology of the Cockfield Formation. Paleobotanical data.

Lonsdale, J. T., 1935, Geology and ground-water resources of Atascosa and Frio Counties, Texas: U.S. Geol. Survey Water-Supply Paper 676, $90 \mathrm{p}$.

Discusses lithology, thickness, and dip of Yegua Formation. Brief discussion of water supply in Yegua. Records of wells are given in table. Geologic map.

Lonsdale, J. T., and Day, J. R., 1937, Geology and groundwater resources of Webb County, Texas : U.S. Geol. Survey Water-Supply Paper 778, 104 p.

Describes geology and stratigraphic relations of Yegua Formation. Prospects of water supply negligible. Geologic and hydrologic map. Geologic cross sections. Records of wells in table.

Meinzer, O. E., and Wenzel, L. K., 1942, Movement of ground water and its relation to head, permeability, and storage, in Physics of the Earth, pt. IX Hydrology: New York, MeGraw-Hill Book Co., p. 444-477.

Mellen, F. F., and McCutcheon, T. E., 1940, Yazoo County mineral resources: Mississippi Geol. Survey Bull. 39, 132 p

Discussion includes description of lithology and exposures of Cockfield and stratigraphic relations. Geologic map.

Monroe, W. H., 1954, Geology of the Jackson area, Mississippi : U.S. Geol. Survey Bull. 986, 133 p.

Describes in detail the geology of Cockfield. Discusses conditions of deposition and stratigraphic relations.

Moore, W. H., Bicker, A. R., Jr., McCutcheon, T. E., and Parks, W. S., 1965, Hinds County geology and mineral resources: Mississippi Geol. Econ. and Topog. Survey Bull. 105, 244 p.

Detailed description of geology of Cockfield Formation. Brief discussion of availability and chemical character of water from the Cockfield. Geologic map and stratigraphicstructural cross sections. Tables show volume of water in place, records of wells, and chemical analyses.

Murray, G. E., 1961, Geology of the Atlantic and Gulf Coastal province of North America: New York, Harper \& Bros., $692 \mathrm{p}$.

Discusses various relations of Cockfield to other formations and cycles. Describes facies variations.

Page, L. V., Newcome, Roy, Jr., Graeff, G. E., Jr., 1963, Water resources of Sabine Parish, Louisiana: Louisiana Geol. Survey and Dept. Public Works Water Resources Bull. 3, $146 \mathrm{p}$. 
Brief description of lithology and thickness variation of Cockfield Formation. Discussion of water quality and potential. Records of wells and chemical analyses in tables.

Parks, W. S., Moore, W. H., McCutcheon, T. E., and Wasson, B. E., 1963, Attala County mineral resources: Mississippi Geol. Econ. and Topog. Survey Bull. 99, 192 p.

Brief description of lower part of Cockfield Formation. Brief discussion of water quality and availability.

Payne, J. N., 1968, Hydrologic significance of the lithofacies of the Sparta Sand: U.S. Geol. Survey Prof. Paper 569-A, 17 p.

Peckham, R. C., Souders, V. L., Dillard, J. W., and Baker, B. B., 1963, Reconnaissance investigation of the ground-water resources of the Trinity River basin, Texas: Texas Water Comm. Bull. 6309, 110 p.

Describes geology of Yegua Formation. Discusses quality and availability of water from the Yegua. Gives data on pumpage for use in irrigation and for municipal supplies. Geologic map and cross sections.

Poole, J. L., 1961, Ground-water resources of East Carroll and West Carroll Parishes, Louisiana: Baton Rouge, Louisiana Dept. Public Works, 174 p.

Detailed description of lithology and mineralogy of Cockfield Formation. Discusses stratigraphic relations, stratigraphy, and structure of the Cockfield. Detailed discussion of the hydrology of the Cockfield. Chemical analyses in table.

Priddy, R. R., 1960, Madison County geology : Mississippi Geol. Survey Bull. 88, 129 p.

Detailed description of Cockfield. Several measured sections. Divides Cockfield into four zones. Brief discussion of water supply.

Rollo, J. R., 1960, Ground water in Louisiana : Louisiana Geol. Survey and Dept. Public Works Water Resources Bull. 1, $84 \mathrm{p}$.

Brief description and discussion of lithology, hydrology, and water-supply potential of the Cockfield Formation.

Sellards, E. H., Adkins, W. S., and Plummer, F. B., 1932, The geology of Texas, Volume I, Stratigraphy : Texas Univ. Bull. 3232, $1007 \mathrm{p}$.

Discusses history of the definition of Yegua Formation. Detailed geologic description of Yegua Formation.

Shafer, G. H., 1965, Ground-water resources of Gonzales County, Texas: Texas Water Devel. Board Rept. 4, 89 p.

Very brief description of geology and character of water in Yegua Formation. Tables show records of wells and chemical analyses.

Sundstrom, R. W., Hastings, W. W., and Broadhurst, W. L., 1948, Public water supplies in eastern Texas: U.S. Geol. Survey Water-Supply Paper 1047, 285 p.

Information on yields, depth of wells, and chemical quality of water for municipalities obtaining water from Yegua Formation.

Tarver, G. E., 1966, Ground-water resources of Houston County, Texas: Texas Water Devel. Board Rept. 18, 86 p.
Brief geologic description of Yegua Formation. Brief discussion of availability and chemical character of water from the Yegua. Geologic map and generalized geologic cross section. Records of wells and chemical analyses in tables.

Theis, C. V., 1935, The relation between the lowering of the piezometric surface and the rate and duration of discharge of a well using ground-water storage: Am. Geophys. Union Trans., 16th Ann. Mtg., v. 16, pt. 2, p. 519-524.

Thomas, E. P., 1942, The Claiborne: Mississippi Geol. Survey Bull. 48, 96 p.

Detailed discussion of the geology and stratigraphic relations of Cockfield Formation. Discussion of depositional conditions during Cockfield time.

Thompson, G. L., 1966, Ground-water resources of Lee County, Texas: Texas Water Devel. Board Rept. 20, 131 p.

Brief description of the geology of the Yegua. Brief reference to availability of water from the Yegua Formation. Geologic map and cross sections. Records of wells and chemical analyses in tables.

Treadwell, R. C., 1954, Moodys Branch-Cockfield contact in Sabine Parish, Louisiana and adjacent areas: Am. Assoc. Petroleum Geologists Bull., v. 38, no. 11, p. 2302-2323.

Describes diastemic relations of Cockfield and Moodys Branch Formations. Describes Cockfield facies underlying Moodys Branch.

Turcan, A. N., Jr.; 1966, Calculation of water quality from electrical logs-theory and practice: Louisiana Geol. Survey and Dept. Public Works Water Resources Pamph. 19, 23 p.

U.S. Public Health Service, 1962, Drinking water standards : U.S. Dept. Health, Education, and Welfare, Public Health Service Pub. 956, p. 7-8.

Varvaro, G. G., 1957, Geology of Evangeline and St. Landry Parishes: Louisiana Geol. Survey Geol. Bull. 31, 295 p.

Brief description of geology of Cockfield Formation in the subsurface of Evangeline and St. Landry Parishes.

Vaughn, T. W., 1895, The stratigraphy of northwestern Louisiana: Am. Geologist, v 15, p. 205-229.

Description of beds and introduction of name "Cockfield."

Wang, K. K., 1952, Geology of Ouachita Parish: Louisiana Geol. Survey Geol. Bull. 28, 126 p.

Fairly detailed geologic description of Cockfield Formation.

White, W. N., Sayre A. N., and Heuser, J. F., 1941, Geology and ground-water resources of the Lufkin area, Texas: U.S. Geol. Survey Water-Supply Paper 849-A, p. 1-58.

Description of lithology of Yegua Formation. Discussion of availability and chemical character of water from the Yegua. Chemical analyses and records of wells in tables.

Winslow, A. G., 1950, Geology and ground-water resources of Walker County, Texas : Texas Board Water Engineers Bull. $5003,48 \mathrm{p}$.

Very brief description of lithology of Yegua Formation. Brief discussion of water potential of the Yegua. Geologic map and cross sections.

Winslow, A. G., and Kister, L. R., 1956, Saline-water resources of Texas : U.S. Geol. Survey Water-Supply Paper 1365, 105 p. 